\title{
INHIBITORY POTENTIAL OF COCONUT AND CARROT OIL EXTRACTS ON SOME BACTERIAL SKIN MICROFLORA
}

\author{
Ewansiha J.U. ${ }^{*}$, Tilon G. ${ }^{1}$, Kolawole I.D. ${ }^{1,2}$ and Orji S.L. ${ }^{3}$ \\ ${ }^{1}$ Department of Microbiology, Federal University of Technology, Yola, Nigeria. \\ ${ }^{2}$ Department of Food Science and Technology, Universidade de Sao Paulo, Brazil. \\ ${ }^{3}$ Bio-resources Development Centre, National Biotechnology Development Agency, Lugbe \\ Abuja.
}

\begin{abstract}
In response to the chemically harmful effects of commercially sold body creams on the skin due to the presence of steroids, hydroquinone and kojic acid, natural oil extracts from medicinal plants and fruits are seen as alternative. The use of natural oil extract is not without some intricacies too as its effect against skin microflora has been reported. Therefore, the inhibitory potentials of coconut and carrot oil extracts on some bacterial skin microflora were determined using standard laboratory identification and agar well diffusion methods for identification of bacteria from human skin swab and antibacterial susceptibility test, respectively. The isolated organisms include, Staphylococcus aureus, Streptococcus species, and Pseudomonas aeruginosa. The result obtained shows that carrot oil extract inhibits all the test isolates with mean zones of inhibition (MZI) ranged from $6.00 \pm 1.00$ to $12.15 \pm 0.55$ while coconut oil extract was only active against Pseudomonas aeruginosa with MZI of $12.50 \pm 0.55$. The minimum inhibitory concentration (MIC) result also shows that carrot oil extract was significantly $(p<0.05)$ more active than coconut oil with MIC of 50\% while the test isolates were still viable at $100 \%$ use of coconut oil extract. There was no minimum inhibitory concentration $(M B C)$ obtained as all the test organisms were still viable at $100 \%$ of both oil extracts. From the result of this study, it can be concluded that carrot oil extract possesses inhibitory potentials against skin microflora as opposed to coconut oil extract. Therefore, it is safer to apply coconut oil on human skin since it has less inhibitory effect on skin microflora.
\end{abstract}

KEYWORD: Carrot Oil, Coconut Oil, Microflora, Inhibitory Activity, Skin Swab

\section{INTRODUCTION}

Skin microflora are microorganisms that resides on skin, typically human skin. Many of these bacteria are mostly found on the superficial layers of the epidermis, and upper part of hair follicles of the human skin (Grice et al., 2009). They colonize the superficial cells specifically the dead cells that are closely associated with oil and sweat glands. The secretions from these glands primarily provides nutrient to the microflora such as the Staphylococcus aureus, Staphylococcus epidermidis and Corynebacterium species. The oil glands produce complex lipids that are broken down to an unsaturated fatty acid (oleic acid) by an enzyme secreted by Propionibacterium acnes (Grice et al., 2009). The oleic acid produced have a very strong antimicrobial activity against gram negative bacteria which could be pathogenic in nature (Willey et al., 2014). Skin flora are non-pathogenic and plays an integral role in the human immune systems as they help to defend its host against invading bacterial pathogens (Dorrestein et al., 2016). Although, resident microflora may become pathogenic in response to 
an impaired skin barrier creating life-threatening diseases, particularly in immunocompromised people (Musharrafieh et al., 2014).

Coconut (Cocos nucifera), an important fruit originating from South-East Asia, is a source of food for millions of people worldwide. The various products of coconut include coconut oil, coconut water, raw kernel, copra, coconut toddy, coconut cake, coconut shell and wood based (Manisha and Shyamapada, 2011). Coconut oil contain naturally vitamin A that is suitable for human consumption without the need for further processing (Davina and Keith, 2006).

Carrot (Daucus Carota) produce diversity of phytonutrients including carotenoids, phenolics, $\alpha$-tocopherol, and polyacetylenes, many of which have antioxidant and other health promoting effects (Metzger and Barnes, 2009). Carrot oil is an essential oil extracted from the seeds of carrot (Staniszewska and Kula, 2001). The main chemical constituents of the oil extract include camphene, $\beta$-bisabolene, $\beta$-pinene, limonene, myrcene, $\alpha$-pinene sabinene, $\gamma$ terpinene, Geranyl acetate and carotene (Staniszewska \& Kula, 2001). These oils have been used as cream on the skin by many locals in folklore due to their natural properties and with low or no chemical effect on the human skin. But their antimicrobial activity has not been fully ascertained, therefore, this study focused on the effect of coconut and carrot oil on some bacteria skin microflora.

\section{MATERIALS AND METHODS}

\section{Sample Collection and Processing}

\section{Coconuts and Carrot}

Matured coconuts (Cocos nucifera) and carrots fruits (Daucus Carota) were purchased from Jimeta ultra market in Yola and was transported to the Microbiology Laboratory, Modibbo Adama University of Technology where they were stored at room temperature for microbiological analysis. The coconut oil was extracted using the modified kitchen method (otherwise call the wet processing method) of Davina and Keith (2006), this was achieved by shredding the fleshy part of the coconuts using manual grater and hot extraction process was used to extract the oil. Also, carrot was shredded, dried, and was processed using domestic blender, while the oil was extracted using cold maceration method by transferring fifty grams $(50 \mathrm{~g})$ of the blended carrot fruit into $250 \mathrm{~mL}$ conical flask containing $200 \mathrm{~mL}$ N-hexane to give a 1: 4 ratio solution as described by Okoduwwa et al. (2016).

\section{Skin swab}

Skin swabs were collected by rubbing sterile cotton swab repeatedly from the body, scalp, and leg. The swabs were placed in a sterile container containing transport medium and they were transported to the laboratory for analysis.

\section{Culture and Identification of Bacterial Isolates}

\section{Culture of bacterial isolates}

All media such as, Blood agar, Triple sugar iron (TSI), Nutrient agar, Nutrient broth and Mueller-Hinton agar used for isolation and antibacterial susceptibility test respectively were 
prepared according to the manufacturer specifications. The samples were inoculated in the culture media using the streaking method and incubated overnight. After incubation, all colonies developed were sub-cultured unto freshly prepared media according to their colonial morphology to obtain pure isolates. All cultures were incubated at $37^{\circ} \mathrm{C}$ for 24 hours.

\section{Gram staining}

Overnight culture of the isolated organisms were Gram stained using the method described by Chessbrough (2002). Gram-negative and gram-positive isolates were recorded. Control smears of known gram-positive organism (Staphylococcus aureus) and a known gram-negative organism (Escherichia coli) were stained simultaneously to standardize the test procedure.

\section{Biochemical Characterization of Isolates}

Biochemical tests were performed according to a method described by Chessbrough (2002) on the isolated microorganisms after microscopic identification, identified as gram negative and gram positive to identify the genus and species of the organisms.

\section{Determination of the Inhibitory Potentials of the Oil Extracts}

\section{Standardization of inoculum}

Suspension of the test organisms was made by inoculating a loopful of the colony into $5 \mathrm{ml}$ of nutrient broth and incubated at $37^{\circ} \mathrm{C}$ for 18 hours. After incubation, $0.2 \mathrm{~mL}$ of the broth culture of each test isolates were diluted in $6 \mathrm{~mL}$ of distilled water to obtain an inoculum size equivalent to McFarland standard of $1 \times 10^{6}$ which is immediately inoculated after dilution (Ewansiha et al., 2017).

\section{Preparation of Extract concentration}

A varying concentration of oils were made using Dimethyl Sulfoxide (DMSO) as a diluent. Each volume of the oil extracts $(2.5 \mathrm{ml}, 5 \mathrm{ml}$, and $7.5 \mathrm{ml})$ were mixed with same volume of Dimethyl sulfoxide. The mixtures were transferred into a $20 \mathrm{ml}$ graduated test tubes and were made up to $10 \mathrm{~mL}$ mark with DMSO.

\section{Antimicrobial Susceptibility Test}

Antimicrobial susceptibility test was done according to the method of Loung et al. (2014) using agar well diffusion method. Mueller-Hinton agar was allowed to solidify, while $0.1 \mathrm{~mL}$ of standardized inoculum was inoculated on the solid media ensuring uniform distribution. A $6 \mathrm{~mm}$ diameter sterile cork bearer was used to make wells in the medium. One hundred microliter $(100 \mu \mathrm{L})$ of the various concentration of oil extracts were transferred into the wells and the plates were allowed to stand on the bench for about 30min to allow proper diffusion of the oils through the culture medium and all plates were incubated at $37^{\circ} \mathrm{C}$ for 24 hours. After incubation, the culture plates were observed for clear zones of inhibition (ZI) which is an indicative of the activity. 


\section{Determination of Minimum Inhibitory Concentration and Minimum Bactericidal Concentration}

According to Lalitha et al. (2004), Mueller-Hinton broth was dispensed into test tubes for each corresponding to the number of test isolates and extracts. Two test tubes were used as control, one each for positive (Chloramphenicol) and negative (DMSO) control. Undiluted oil extract $(4 \mathrm{~mL})$ was transferred into a first test tube (100\% concentration) while equivalent amount of oil extract, DMSO and Mueller-Hinton broth in the ratio 2:1:1 (4mL in total) was transferred into the second test tube to give a concentration of $50 \%$. Two $\mathrm{mL}$ from the second test tube was transferred into the third test tube containing one part each of DMSO and Mueller-Hinton broth to give a reducing concentration of $25 \%$. This process continued until a concentration of $0.78 \%$ was obtained in the last test tube. Each tubes were inoculated with $100 \mu \mathrm{L}$ of the test organisms and incubated for 24 to 48 hours at $37^{\circ}$. Growth were observed in the form of turbidity after incubation and the lowest concentration without visible growth were taken as the minimum inhibitory concentration (MIC), while the tubes without turbidity, beginning with the MIC tube were sub-cultured unto freshly prepared medium to determine the minimum bactericidal concentration. All plates were observed for viability after incubation at $37^{\circ} \mathrm{C}$ for 24 hours.

\section{RESULTS}

Table 1: Isolates from human skin and scalp

\begin{tabular}{cc}
\hline Skin Swab Sample & Isolates \\
\hline Arm Swab and Scalp Swab. & Staphylococcus aureus \\
Face Swab and Arm Swab. & Streptococcus species \\
Leg Swab. & Pseudomonas aeruginosa \\
\hline
\end{tabular}

Table 2: Mean Zones of Inhibition Exhibited by Carrot Oil (mm)

\begin{tabular}{|c|c|c|c|c|c|c|}
\hline \multirow[b]{2}{*}{ Isolates } & \multicolumn{4}{|c|}{ Carrot Oil Extract (\%) } & \multicolumn{2}{|c|}{ Control } \\
\hline & 100 & 75 & 50 & 25 & Cpl (1mg) & $\begin{array}{c}\text { DMSO } \\
(100 \mu L)\end{array}$ \\
\hline $\begin{array}{l}\text { Staphylococcus } \\
\text { aureus }\end{array}$ & $\begin{array}{c}11.20 \pm 0.5 \\
7^{\mathrm{c}}\end{array}$ & $\underset{\mathrm{b}}{10.0 \pm 1.50}$ & $\begin{array}{c}8.65 \pm 0.1 \\
5^{\mathrm{a}}\end{array}$ & $\begin{array}{c}7.05 \pm 0.2 \\
2^{\mathrm{a}}\end{array}$ & $\begin{array}{c}21.00 \pm 0.5 \\
7^{\mathrm{d}}\end{array}$ & NA \\
\hline $\begin{array}{l}\text { Streptococcus } \\
\text { species }\end{array}$ & $\begin{array}{c}12.15 \pm 0.5 \\
5^{c}\end{array}$ & $\begin{array}{c}10.05 \pm 0.5 \\
7^{b}\end{array}$ & $\begin{array}{c}9.33 \pm 0.2 \\
2^{b}\end{array}$ & $\begin{array}{c}6.00 \pm 1.0 \\
0^{\mathrm{a}}\end{array}$ & $\begin{array}{c}24.30 \pm 1.4 \\
0^{\mathrm{d}}\end{array}$ & NA \\
\hline $\begin{array}{l}\text { Pseudomonas } \\
\text { aeruginosa }\end{array}$ & $\begin{array}{c}11.22 \pm 0.5 \\
2^{\mathrm{c}}\end{array}$ & $\frac{9.20 \pm 0.57}{b}$ & $\begin{array}{c}7.00 \pm 0.1 \\
0^{\mathrm{a}} \\
\end{array}$ & $\begin{array}{c}6.00 \pm 1.0 \\
0^{\mathrm{a}} \\
\end{array}$ & $\begin{array}{c}30.02 \pm 0.8 \\
8^{\mathrm{d}}\end{array}$ & NA \\
\hline
\end{tabular}

Key: $C p l=$ Chloramphenicol, DMSO=Dimethyl sulphoxide. Values on the same column with different superscript are significantly different $(p<0.05)$. 
African Journal of Biology and Medical Research

ISSN: 2689-534X

Volume 3, Issue 3, 2020 (pp. 15-21)

www.abjournals.org

Table 3: Zones of Inhibition Exhibited by Coconut Oil (mm)

\begin{tabular}{|c|c|c|c|c|c|c|}
\hline \multirow[b]{2}{*}{ Isolates } & \multicolumn{4}{|c|}{ Coconut Oil Extract (\%) } & \multicolumn{2}{|c|}{ Control } \\
\hline & 100 & 75 & 50 & 25 & Cpl (1mg) & $\begin{array}{c}\text { DMSO } \\
(100 \mu \mathrm{L})\end{array}$ \\
\hline $\begin{array}{l}\text { Staphylococcus } \\
\text { aureus }\end{array}$ & NA & NA & NA & NA & $\begin{array}{c}21.00 \pm 0.5 \\
7^{\mathrm{a}}\end{array}$ & NA \\
\hline $\begin{array}{l}\text { Streptococcus } \\
\text { species }\end{array}$ & NA & NA & NA & NA & $\begin{array}{c}24.30 \pm 1.4 \\
0^{\mathrm{a}}\end{array}$ & NA \\
\hline $\begin{array}{l}\text { Pseudomonas } \\
\text { aeruginosa }\end{array}$ & $\begin{array}{c}12.50 \pm 0.5 \\
5^{\mathrm{a}}\end{array}$ & NA & NA & NA & $\begin{array}{c}30.02 \pm 0.8 \\
8^{\mathrm{b}}\end{array}$ & NA \\
\hline
\end{tabular}

Key: $C p l=$ Chloramphenicol, DMSO=Dimethyl sulphoxide. Values on the same column with different superscript are significantly different $(p<0.05)$

Table 4: Minimum Inhibitory Concentration (MIC) and Minimum Bactericidal Concentration (MBC) of Carrot Oil Extract

\begin{tabular}{lccccccccccc}
\hline & \multicolumn{10}{c}{ Carrot Oil Extract (\%) } \\
MICRORGANISMS & $\mathbf{1 0 0}$ & $\mathbf{5 0}$ & $\mathbf{2 5}$ & $\mathbf{1 2 . 5}$ & $\mathbf{6 . 2 5}$ & $\mathbf{3 . 1 3}$ & $\mathbf{1 . 6 0}$ & $\mathbf{0 . 7 8}$ & MIC & MBC \\
\hline Staphylococcus aureus & - & - & + & + & + & + & + & + & 50 & + \\
Streptococcus species & - & - & + & + & + & + & + & + & 50 & + \\
Pseudomonas & - & + & + & + & + & + & + & + & 100 & + \\
aeruginosa & & & & & & & & & & \\
\hline
\end{tabular}

Keys: "+" = Growth Occurrence, "-” = No growth Occurrence, MIC = Minimum inhibitory concentration, $M B C=$ minimum bactericidal concentration.

Table 5: Minimum Inhibitory Concentration (MIC) and minimum Bactericidal Concentration (MBC) of Coconut oil Extract

\begin{tabular}{|c|c|c|c|c|c|c|c|c|c|c|}
\hline \multirow[b]{2}{*}{ Isolates } & \multicolumn{8}{|c|}{ Coconut Oil Extract (\%) } & \multirow{2}{*}{$\begin{array}{r}\text { MIC } \\
(\%)\end{array}$} & \multirow[t]{2}{*}{ MBC } \\
\hline & 100 & 50 & 25 & 12.5 & 6.25 & 3.13 & 1.60 & 0.78 & & \\
\hline Staphylococcus aureus & + & + & + & + & + & + & + & + & + & + \\
\hline Streptococcus species & + & + & + & + & + & + & + & + & + & + \\
\hline $\begin{array}{l}\text { Pseudomonas } \\
\text { aeruginosa }\end{array}$ & - & - & + & + & + & + & + & + & 50 & + \\
\hline
\end{tabular}

Keys: “+” = Growth Occurrence, “-” = No growth Occurrence, MIC = Minimum inhibitory concentration, $M B C=$ minimum bactericidal concentration . 


\section{DISCUSSION}

The result of this study showed that both gram positive (Staphylococcus aureus and Streptococcus specie) and gram-negative bacteria (Pseudomonas aeruginosa) were isolated from human skin swabs. The carrot oil extract was more effective at $100 \%$ concentration against the test organisms, but the activity got reduced with reduction in the concentration. This revealed that the activity of the carrot oil extract was concentration dependent. This could be because of the differences in the physiological makeup of the organism's cell wall. Although, gram negative bacterial was more resistance to this oil than gram positive bacteria and this could be attributed to the fact that Gram negative bacteria possess an outer lipid membrane in addition to the peptidoglycan layer. This study showed similar result with Staniszweska et al (2005) that stated that gram positive bacteria are more sensitive to carrot oil than gram negative bacteria. Coconut oil was only effective against Pseudomonas aeruginosa at $100 \%$ concentration and no inhibitory activity was seen on other isolates at all examined concentrations which is in contrast with the report of Abas et al. (2017) that coconut oil showed inhibitory effect against gram positive bacteria which he attributed to the presence of lauric acid and capric acid. Therefore, the difference in the results could be attributed to the different extraction process used. Staniszewska et al. (2011) stated that inhibitory activity of oils depends on their chemical composition. Carrot oil is known to contain 3 flavones viz. luteolin, luteolin 3'-o-beta-D-glucopyranoside and luteolin 4'-o-beta-D-glucopyranoside which could be responsible for its antibacterial activity. The coconut oil could be less active due to the fact that heat was applied in its extraction process, and this also is in tandem with the report of Sukhdev et al. (2008) that heat could prevent the extraction of some active compounds in medicinal plants. But on the contrary, carrot oil was extracted without the application of heat, which might explain its high effectiveness against the test isolates.

\section{CONCLUSION AND RECOMMENDATION}

From the results presented in this study, carrot oil was found to possess more inhibitory effect on isolated microorganisms than coconut oil. Thereby, coconut oil appeared to be safer for application on the skin since it has less inhibitory effect on skin microflora.

\section{REFERENCES}

Abbas, A. A., Ernest, B. A., Akeh, M., Upla, P., and Tuluma, T. K. (2017). Antimicrobial Activity of Coconut Oil and its Derivative (Lauric Acid) on Some Selected Clinical Isolates. International Journal of Medical Science and Clinical Inventions. 4 (8), 31733177.

Chessbrough, M. (2002). District laboratory practice in tropical countries part II; Cambridge university press $U K, 138-142$.

Davina, D. B. and Keith, R. C. (2006). Virgin Coconut oil production manual for micro- and village- scale processing. National Library, Bangkok Cataloguin-In-Publication data. www.fao.org/world/regional/rap/highlights.asp

Dorrestein, P.C., Gallo, R.L and Knight, R. (2016). Microbial skin inhabitants: friends forever. Cell, 165(4):771-2 
Ewansiha J. U., Garba S. A., Galadima M., Daniyan S. Y., Busari M. B and Doughari J. H (2017). Bioactivity of Chromatographic Fractions from Eucalyptus citriodora Leaf against Some Bacterial Pathogens, International Journal of Clinical Medicine Research; 4(1): 1-14

Grice, E. A., Kong, H. H and Conlan, S. (2009). Topographical and Temporal Diversity of the Human Skin Microbiome. Science 324, (5931), 1190-1192.

Lalitha, M.K, (2004). Manual on antimicrobial susceptibility test. Indian association of medical microbiologists, Pp: 12-17.

Loung F. S., Silalahi J. and Suryanto D. (2014). Antibacterial activity of Enzymatic hydrolyzed of Virgin Coconut oil and Palm Kernel oil against Staphylococcus aureus, Salmonella Typhi and Escherichia coli. International Journal of PharmTech Research, 6 (2): 628-633.

Manisha, D and Shyamapada, M. (2011). Coconut (Cocos nucifera L.: Arecaceae): In health promotion and disease prevention. Asia pacific journal of Tropical Medicine, Pp: 241247.

Metzger, B.T and Barners, D.M., (2009). Polyacetylene diversity and bioactivity in orange market and locally grown colored carrots (Daucus carota L.). Journal of Agricultural and Food Chemistry, 57: 1134-1139.

Musharrafieh, R., Tacchi, L., Trujeque, J., LaPatra, S and Salinas, I. (2014). Staphylococcus warneri, a resident skin commensal of rainbow trout (Oncorhynchus mykiss) with pathobiont characteristics. Vertenary Microbiology, 169 (1-2): 80-88.

Okoduwa, R. I. S., Umar, I. A., James, D. B., Inuwa, M. and Habila, J. D. (2016). Evaluation of extraction protocols for anti-diabetic phytochemical substances from medicinal plants. World journal of diabetes. 7 (20): 605-614.

Staniszewska, M and Kula, J. (2001). Composition of the essential oil from wild carrot umbels (Daucus carota) growing in Poland ||. Journal of Essential Oil Resources, 13: 439-441.

Staniszewska, M., Kula, J., Wiecorkiewicz, M. and Kusewicz, D. (2005). Essential oils of wild and cultivated carrots, the chemical composition and antimicrobial activity. The journal of Essential oil Research.17 (5): 579-583.

Staniszewska, M., Kula, J., Wieczorkiewicz, M and Kusewicz, D. (2005) Essential Oils of Wild and Cultivated Carrots - the Chemical Composition and Antimicrobial Activity, Journal of Essential Oil Research, 17 (5): 579-583.

Sukhdev S.H., Suman, P. S. K., Gennaro, L and Dev, D. R. (2008). Extraction Technologies for Medicinal and Aromatic Plants. International Centre for Science and High Technology, Trieste, 11.

Willey, J.M., Sherwood, M.L and wooherton, C.J. (2014). Prescott's microbiology, $9^{\text {th }}$ edition. McGraw Hill, 718-719.

Copyright (C) 2020 The Author(s). This is an Open Access article distributed under the terms of Creative Commons Attribution-NonCommercial-NoDerivatives 4.0 International (CC BYNC-ND 4.0), which permits anyone to share, use, reproduce and redistribute in any medium, provided the original author and source are credited. 